\title{
TOKSISITAS TIMBAL (Pb) TERHADAP KESEHATAN IKAN
}

\author{
Nazariah Hayatun ${ }^{1}$ \\ ${ }^{1}$ Mahasiswa Program Studi Aquakultur. Fakultas Pertanian, Universitas Almuslim, Jalan Almuslim, Matang Geulumpang Dua, \\ Peusangan, Kabupaten Bireuen, Aceh 24261 \\ Email: nazariah.hayatun@gmail.com
}

\begin{abstract}
ABSTRAK
Logam berat $(\mathrm{pb})$ yang tercemar masuk ke dalam tubuh organisme dapat menyebabkan penumpukan bahan pencemar dalam jaringan terutama di organ-organ yang rentan terhadap pencemaran lingkungan perairan. Uji penelitian terhadap organ-organ ikan yang meliputi jaringan hati yang terpapar logam timbal mengakibatkan hati mengalami degenerasi lemak karna terpapar konsentras timbal yang lebih tinggi, ginjal menyebabkan terakumulasi bahan toksik yang masuk ke dalam tubuh ikan sehingga akan terlihat perubahan atau kerusakan pada jaringan ginjal ikan, pada usus terjadinya kerusakan edema pada jaringan tersebut, dan pada insang menyebabkan kerusakan jaringan pada lamela primer dan lamela sekunder sehingga terjadinya hiperplasia.
\end{abstract}

Kata kunci: Toksisitas, Logam timbal, Organ Ikan

\section{PENDAHULUAN}

Toksisitas merupakan suatu efek yang merugikan dari bahan kimia dan bersifat negatif bagi semua ataupun sebagian makhluk hidup, baik itu sel, jaringan, organ, individu ataupun populasi. Efek yang ditimbulkan dapat merusak fungsi fisiologis dan struktur (Megawati, 2015). Meningkat nya kadar zat-zat pencemar yang berbahaya dapat menimbulkan toksik atau racun sehingga mengganggu proses kehidupan dan setelah mencapai kadar tertentu dapat mematikan hewan peliharaan (Zulfahmi et al., 2017); (Zulfahmi et al., 2018); (Akmal et al., 2018d); (Muliari et al., 2019a); (Muliari et al., 2019b). Salah satu bahan pencemar yang dapat menimbulkan efek negatif bagi biota perairan adalah logam berat. Faktor lingkungan seperti toksik perairan dari dan kelainan genetik dapat mempengaruhi keabnormalan tulang rangka ikan (Zulfahmi et al., 2018); (Akmal et al., 2018a); (Akmal et al., 2018b); (Akmal et al., 2018c); (Akmal et al., 2019); (Zulfahmi et al., 2019). Hal ini dapat disebabkan jika sejumlah logam telah timbul efek dan ditemukan dalam konsentrasi tinggi dalam perairan. logam berat terbagi antara 2 yaitu logam essensial dan logam non essensial. logam essensial adalah logam yang sangat membantu dalam proses fisiologis makhluk hidup dengan cara membantu kerja enzim atau pembentukan organ dari organisme yang berkaitan. Sedangkan logam non essensial adalah logam yang peranannya dalam tubuh makhluk hidup belum diketahui, kandungannya dalam jaringan hewan sangat dikit, dan apabila kandungannya tinggi maka dapat merusak organ-organ tubuh makhluk yang bersangkutan. Timbal $(\mathrm{Pb})$ adalah salah satu logam berat yang terdapat dalam perairan (Darmono,1995).

Timbal $(\mathrm{Pb})$ adalah salah satu jenis logam berat yang dapat menyebabkan pencemaran dalam perairan. Dalam suatu perairan yang tercemar oleh timbal $(\mathrm{Pb})$ akan berdampak negatif didalam organisme perairan. Logam timbal $(\mathrm{Pb})$ dapat masuk ke dalam tubuh makhluk hidup melalui rantai makanan, insang atau difusi melalui permukaan kulit, akibatnya toksit ikan itu dapat terserap dalam jaringan, tertimbun dalam jaringan (bioakumulasi) dan pada konsentrasi tersebut akan dapat merusakan organ dalam jaringan tubuh (Palar, 1994). Toksisitas logam timbal $(\mathrm{Pb})$ terhadap organisme air dapat menyebabkan kerusakan jaringan organisme khususnya pada organ ikan seperti insang dan usus kemudian ke jaringan bagian dalam seperti hati dan ginjal tempat logam tersebut terakumulasi (Darmono, 2001).

Toksisitas logam timbal $(\mathrm{Pb})$ terhadap organisme air yang dapat menyebabkan kerusakan jaringan organisme khususnya pada organ ikan seperti insang dan usus kemudian pada jaringan bagian dalam seperti hati dan ginjal tempat logam tersebut terakumulasi (Darmono, 2001). Hati merupakan organ yang berfungsi dalam mensekresikan bahan untuk proses pencernaan. Organ ini umumnya merupakan suatu kelenjar yang kompak, berwarna merah kecoklatan (Affandi dan Tang, 2002). Hati merupakan organ yang sangat sensitif terhadap pengaruh zat kimia dan sangat peka terhadap toksikan zat kimia.Menurut Lu (1995) Sebagian besar toksikan yang masuk ke dalam tubuh setelah diserap sel epitel usus halus akan dibawa ke hati oleh vena porta hati. Organ hati sangat sensitif terhadap pengaruh berbagai zat kimia dan merupakan organ tubuh yang sering mengalami kerusakan. Pengamatan kerusakan pada hati dapat dilakukan dengan pengamatan secara histologi. Menurut penelitian Alifia dan Djawad (2000),efek toksikan timbal juvenile ikan bandeng yang tercemar dapat memperlihatkan bahwa hati mengalami perubahan pada konsentrasi tertentu. Logam berat tersebut juga dapat menyerang pada organ ikan lainnya seperti insang.

Menurut Saputra et al,. (2013) insang ikan merupakan organ utama yang berperan dalam pertukaran ion bekerja dengan mekanisme difusi permukaan dari gas-gas respirasi (oksigen dan karbondioksida) antara darah dan air, dengan demikian perubahan-perubahan lingkungan perairan akan secara langsung berdampak kepada struktur. Organ selanjutnya yang terpapar logam berat timbal yaitu pada pencernaan (usus). Menurut Priosoetyanto (2010) Usus merupakan salah satu organ yang mudah terpapar oleh penyakit. Jaringan selanjutnya yang merusak organ adalah ginjal. Menurut Stine dan Brown (1996) Ginjal merupakan bentuk tempat ekskresi 
zat-zat ekskresi yang tidak diperlukan tubuh seperti senyawa nitrogen, asam urat dan bahan-bahan beracun yang terbawa dalam sistem sirkulas darahi, mengatur keseimbangan, air dan elektrolit dalam tubuh dan mempertahankan keseimbangan asam-basa menghasilkan hormon rennin.

\section{PEMBAHASAN}

\section{Kerusakan organ ikan akibat dampak timbal (pb)}

Pengaruh timbal terhadap organ yang tepapar dapat dilihat dengan adanya perubahan dan kerusakan organ ikan yang terpapar bahan toksik (logam berat) yang masuk ke dalam tubuh ikan, logam berat pada akumulasi tertentu dapat merusak jaringan dalam organ-organ tubuh ikan misalnya pada organ insang, hati, ginjal dan usus (Camargo dan Martinez 2007). Menurut Permatasari (2015), Pb yang terdapat didalam tubuh ikan dapat menyebabkan toksisitas (beracun), setelah di amati jaringan hati pada ikan telah mengalami kerusakan. Kontaminasi $\mathrm{Pb}$ terhadap hati ikan dengan konsentrasi (0.05) ppm memperlihatkan perubahan bentuk, terlihat pada sel hati mengalami degenerasi lemak. Degenerasi lemak terjadi karena adanya penumpukan lemak (lemak netral) dengan kerusakan inti sel dan menciutnya jaringan sel hati (Panigoro et al, 2007).

\section{Kerusakan pada hati}

Menurut Lu (1995) menyatakan bahwa hati sangat rentan terhadap pengaruh zat kimia dan menjadi organ sasaran utama dari zat beracun. Hal ini terjadi karena sebagian besar racun atau zat toksik yang masuk ke dalam tubuh dan diserap oleh sel selanjutnya akan dibawa ke hati oleh vena porta hati, sehingga hati berpotensi mengalami kerusakan. Kerusakan hati akibat logam berat $(\mathrm{Pb})$ disebabkan aktifitas $\mathrm{Pb}$ tersebut dalam mempengaruhi aktifitas enzim. Hal tersebut terjadi karena telah terpapar zat toksik $(\mathrm{Pb})$.

Menurut Alifia dan Djawad (2000) menyebutkan bahwa ikan Bandeng (Chanos chanos) yang terpapar logam timbal mengakibatkan hati mengalami degenerasi lemak. Degenerasi lemak ditandai dengan penampakan histologi berupa vakuolavakuola. Dan Menurut Silviany (2004) menyebutkan bahwa ikan Mas yang terpapar logam timbal mengakibatkan hati mengalami degenerasi lemak sehingga fungsi hati yang lengkap menjadi hilang. Menurut Darmono (1995) tingkat kerusakan hati dikategorikan menjadi tiga, tingkat ringan yaitu perlemakan hati yang ditandai dengan membesarnya sel. Kerusakan tingkat sedang yaitu kongesti dan hemoragi, sedangkan tingkat berat ditandai dengan nekrosis. Selain hati logam berat $(\mathrm{Pb})$ juga menyerang pada organ ikan lainnya seperti ginjal.

\section{Kerusakan pada ginjal}

Menurut Stine dan Brown (1996) ginjal adalah organ yang berfungsi mensekrersi zat - zat yang tidak dibutuhkan tubuh seperti senyawa nitrogen, asam urat dan bahan-bahan beracun yang terbawa dalam sistem sirkulasi darah, mengatur keseimbangan, air dan elektrolit dalam tubuh dan mempertahankan keseimbangan asam-basa dan menghasilkan hormon rennin. Dalam uji tersebut telah ditemukan perubahan histopatologis. Ginjal merupakan salah satu organ yang mudah terpapar bahan toksik yang masuk ke dalam tubuh ikan, sehingga apabila adanya bahan toksik masuk ke dalam tubuh ikan, maka akan memperlihatkan perubahan atau kerusakan pada jaringan ginjal ikan.

Pada uji pengamatan dapat terlihat bahwa organ ginjal yang terpapar oleh logam berat $(\mathrm{Pb})$, mengalami kerusakan akibat daya toksik logam berat tersebut. Jaringan ginjal ikan lebih rapuh dan konsistensinya lebih lunak. Ginjal lebih sensitif terhadap limbah toksik karena ginjal mempunyai peran utama dalam ekskresi metabolisme, pencernaan dan tempat penyimpanan berbagai unsure senyawa. Menurut Natalia (2007) ginjal berfungsi untuk menyaring dan membuang bahan yang tidak dibutuhkan oleh tubuh, termasuk zat toksit.

\section{Kerusakan pada insang}

Insang ikan merupakan organ utama yang berperan dalam pertukaran ion bekerja dengan mekanisme difusi permukaan dari gas-gas respirasi (oksigen dan karbondioksida) antara darah dan air, dengan demikian perubahan-perubahan lingkungan perairan akan secara langsung berdampak kepada struktur (Saputra 2013). Insang ikan sensitif terhadap parasit, bakteri dan penyakit jamur serta sangat sensitif terhadap perubahan fisik dan kimiawi yang ada dalam media air. Pada pengamatan dilihat terjadi perubahan terhadap insang yang sangat detail, yaitu terjadinya kerusakan jaringan pada lamela primer dan lamela sekunder, dimana terjadinya hiperplasia. Hiperplasia gill lamela adalah pertambahan volume (hiperplasia) lamela insang akibat bertambahnya jumlah sel. Hiperplasia sel-sel lamela insang merupakan perubahan patologis yang paling umum terjadi pada insang. Hiperplasia juga mengakibatkan penebalan jaringan epitel di ujung filamen yang memperlihatkan bentuk seperti pemukul bisbol (clubbing distal) atau penebalan jaringan epitelium yang berada di dekat dasar lamela (basal hiperplasia). Hiperplasia ini dapat terjadi akibat stimuli kimia dari polutan-polutan, infeksi parasit, bakteri, defisiensi asam pantotenat dan bentuk pencemaran lingkungan yang lain, misalnya $\mathrm{pH}$ yang rendah (Feist, et al,. 2003).

\section{Kerusakan pada sistem pencernaan (Usus)}

Usus merupakan salah satu organ yang mudah terpapar oleh penyakit. Pada kondisi perairan yang tercemar, menyebabkan usus berupa edema. Hal ini membuktikan bahwa tingkat kerusakan jaringan usus dipengaruhi oleh logam berat timbal itu sendiri. Semakin tinggi akumulasi timbal pada tubuh ikan maka semakin besar tingkat kerusakan jaringan usus. Edema adalah suatu keadaan dimana terjadinya peningkatan jumlah cairan pada kompartemen intraseluler. Hasil pengamatan menunjukkan bahwa edema terjadi di bagian mukosa usus (Hanna, et al,. 2005).

\section{KESIMPULAN}

Logam berat $(\mathrm{pb})$ yang tercemar masuk ke dalam tubuh organisme dapat menyebabkan penumpukan bahan pencemar dalam jaringan terutama di organ-organ yang rentan terhadap pencemaran lingkungan perairan. Uji penelitian terhadap organ-organ ikan yang meliputi jaringan hati yang terpapar logam timbal mengakibatkan hati mengalami degenerasi lemak karna terpapar konsentras timbal yang lebih tinggi, ginjal menyebabkan terakumulasi bahan toksik yang masuk ke dalam tubuh ikan sehingga akan terlihat perubahan atau kerusakan pada jaringan ginjal ikan, pada usus terjadinya kerusakan edema pada jaringan tersebut, dan pada insang menyebabkan kerusakan jaringan pada lamela primer dan lamela sekunder sehingga terjadinya hiperplasia.

\section{DAFTAR PUSTAKA}

Affandi, R. dan Tang, U. M. (2002). Fisiologi Hewan Air. UNRI Press, Pekanbaru, Riau.

Akmal, Y., Saifuddin, F., \& Zulfahmi, I. (2018). Anatomi Skeleton Ikan Keureling. In Prosiding Seminar Nasional (Vol. 1, No. 1). 
Akmal, Y., \& Rahardjo, M. F. (2018). Morphology of appendicular skeleton of the Thai mahseer's Tor tambroides (Bleeker, 1854). Jurnal Iktiologi Indonesia, 18(3),261-274. https://doi.org/10.32491/jii.v18i3.443

Akmal, Y., Zulfahmi, I., \& Saifuddin, F. (2018). Karak-teristik morfometrik dan skeleton ikan keureling (Tor tambroides Bleeker 1854). Jurnal Ilmiah Samudra Akuatika, 2(1), 35-44.

Akmal, Y., Zulfahmi, I., Juanda, R., Karja, N. W. K., \& Nisa, C. (2018, December). Histopathological changes in gill of Nile tilapia (Oreochromis niloticus) after palm oil mill effluent exposure. In IOP Conference Series: Earth and Environmental Science (Vol. 216, No. 1, p. 012003). IOP Publishing.

Akmal, Y., Saifuddin, F., \& Zulfahmi, I. (2019). Karakteristik Morfometrik Dan Studi Osteologi Ikan Keureling. Prosiding Biotik, 5(1).

Alifia, F dan Djawad, M.I. (2000). Kondisi Histologi Insang dan Organ dalam Juvenil Ikan Bandeng (Chanos Chanos Forskall) yang Tercemar Logam Timbal (Pb).

Camargo, MMP,. Martinez, CBR. (2007). Histopathology of Gills, Kidney and Liver of a Neotropical fish Caged in an Urban Stream. Journal of Neotropical Ichtyology 5 (3): 327-336.

Darmono. (1995). Logam dalam Sistem Biologi Air. Jakarta: UI Press.

Darmono. (2001). Lingkungan Hidup dan Pencemaran. UIPress. Jakarta

Feist, S., Thain, J., Forlin, C,. (2003). Molecular or cellular Process and The Health of The Individual. 147-152. In A. J Lawrence and K. L Hemingway (Eds.). Effects of Pollution on Fish. Blackwell Publishing. UK

Hanna, M, I., Shaheed, I, B. dan Elias, N.S. (2005). A Contribution on Chromium and Lead Toxicity in Cultured (Oreochromis niloticus). Egyption J. Aquat. Biol. Fish. (9): 177-209.

Lu, C.F. (1995). Toksikologi Dasar. Jakarta: Universitas Indonesia.

Megawati, I. A. (2015). Uji Toksisitas Deterjen Terhadap Ikan Nila (Orechromis niloticus). Jurnal Skripsi. FKIP UMRAH. 1 - 10.

Muliari, M., Zulfahmi, I., \& Akmal, Y. (2019). Ekotoksikologi
Akuatik. Bogor: IPB Press.

Muliari, M., Zulfahmi, I., Akmal, Y., Karja, N. W. K., Nisa, C., \& Sumon, K. A. (2019b). Effects of palm oil mill effluent on reproductive hormone of female nile tilapia, oreochromis niloticus (linnaeus 1758). Adv. Anim. Vet. Sci, 7(11), 1035-1041.

Natalia, M,. (2007). Pengaruh Pb terhadap Struktur Insang Ikan Mas (Cyprinus carpio, L). Jurnal Perikanan dan Kelautan 12, 1 (2007): 42-47.

Palar, H. (1994). Pencemaran dan Toksikologi Logam Berat. Rineka Cipta. Jakarta.

Panigoro, N., A. Indri., B. Meliya., Salifira., D.C. Prayudha., dan Kunika, W. (2007). Teknik Dasar Histologi dan Atlas Dasar-dasar Histopatologi Ikan. Balai Budidaya Air Tawar dan Japan International Coperation Agency (JICA). Jambi.

Priosoetyanto, B, P, dkk. (2010). Gambaran Histopatologi Insang, Usus, dan Otot Ikan Mujair (Oreochromis mossambicus) yang Berasal dari Daerah Ciampea, Bogor. Indonesian Journal of Veterinary Science dan Medicine Vol II No.1, Desember 2010.

Saputra, H. M., Marusin, N., dan Santoso, P. (2013). Struktur Histologi Insang dan Kadar Hemoglobin Ikan Asang (Osteochilus hasseltii C.V) di Danau Singkarak dan Maninjau, Sumatera Barat. J. Bio. UA. 2303-2162.

Silviany, V. (2004). Pengaruh Timbal terhadap Morfologi dan Histologi Hati Ikan Mas (Cyprinus Carpio). Skripsi. Jurusan Biologi. Fakultas Matematika dan Ilmu Pengetahuan Alam. Universitas Sriwijaya. Palembang.

Stine, K.E. and Brown, T.M. (1996). Principles of Toxicologi. CRCressInc. Lewis publ.

Zulfahmi, I,. Muliari, Akmal, Y,. Batubara AS. (2018) Reproductive performance and gonad histopathology of famale Nile Tilapia (Orechromis niloticusLinnaeus 1758). Exposed to palm oil mill effluent. The EgyptianJournal of Aquatic Research 44: 327-332.

Zulfahmi, I., Akmal, Y., \& Batubara, A. S. (2018). The morphology of Thai mahseer's Tor tambroides (Bleeker, 1854) axial skeleton (ossa vertebrae). Jurnal Iktiologi Indonesia, 18(2), 139-149.

Zulfahmi, I., Akmal Y., Muliari. (2019). Osteologi Ikan Keureling (Tor tambroides). Bogor: IPB Press; ISBN: 978-602-440-641-7. 